\title{
Seawater desalination in micro grids: an integrated planning approach
}

\author{
Kristina Bognar ${ }^{1 *}$, Philipp Blechinger ${ }^{1,2}$ and Frank Behrendt ${ }^{1}$
}

\begin{abstract}
Background: Islands often depend on the import of fossil fuels for power generation. Due to the combined effect of high oil prices and transportation costs, energy supply systems based on renewable energies are already able to compete successfully with fossil fuel systems for a number of these islands. Depending on local and regional conditions, not only energy supply is a challenge, but also the finding of a reliable supply of water. A promising alternative to freshwater shipments is seawater desalination. Desalination processes can act as a flexible load whenever excess electricity generated by renewable sources is present.

Methods: Numerical simulations of combined energy and water supply systems for the Caribbean island Petite Martinique, Grenada, are accomplished. Considering renewable energy sources like wind and solar radiation, energy storage technologies, and desalination processes, various scenarios are introduced and simulated, and the results are compared.

Results: An extension of the current energy supply system with renewable energy technologies reduces power generation costs by approximately $40 \%$. The excess energy generated by renewables can supply a significant share of a desalination plant's energy demand. The levelized costs of electricity and water show that the integration of desalination as a deferrable load is beneficial to the considered micro grid.

Conclusions: The implementation of renewable energy generation and desalination as deferrable load is recommendable in Petite Martinique. Possible refinancing strategies depending on the combination of different electricity and water tariffs can be derived and applied to similar business cases in remote regions.
\end{abstract}

Keywords: Water cogeneration, Renewable energies, Techno-economic optimization, Demand side management

\section{Background}

Globally, islands depend on the import of fossil fuels for energy production. Due to the combined effect of transportation costs and high oil prices (often being two or three times higher than onshore market prices [1]), energy supply systems based on renewable energies are already able to compete successfully with fossil fuel systems [2-4].

In tropical, dry, and also some moderate climate zones, the main energy form needed is electricity; heating services are hardly required. Cooling services and refrigeration demand are usually met by electricity. In remote and arid regions, there is not only a need to guarantee

\footnotetext{
*Correspondence: kristina.bognar@tu-berlin.de

${ }^{1}$ Department of Energy Engineering, Technische Universität Berlin,

Fasanenstrasse 89, Berlin, 10623, Germany

Full list of author information is available at the end of the article
}

power generation, but also supplying freshwater is a common challenge. Global desertification and excessive usage of natural freshwater reservoirs diminish accessible water stocks. On islands, the unlimited usage of groundwater results in an inflow of seawater from nearby coastlines, leading to increased salt levels and making the previous freshwater unfit for human consumption and other applications.

Many islands, therefore, depend highly on freshwater imports. Ecologically friendly seawater desalination could provide a promising alternative that offers a reliable and, in many cases, less expensive water supply than the import by ships $[5,6]$.

Depending on the technical process used, either thermal (distillation) or electrical (e.g., membrane-based filtration) energy is needed in order to desalinate seawater.

\section{照 Springer}

(c) 2012 Bognar et al: licensee Springer. This is an Open Access article distributed under the terms of the Creative Commons Attribution License (http://creativecommons.org/licenses/by/2.0), which permits unrestricted use, distribution, and reproduction in any medium, provided the original work is properly cited. 
Developing standard solutions for desalting seawater using renewable energies is a widespread goal, $c f$., e.g., [7-11].

Besides conventional energy storage technologies, desalination units could be considered as flexible energy sinks whenever excess energy generated by renewable energy sources is available. Possible ecological and economical benefits of combining power generation with the production of freshwater were investigated by Kaldellis et al. [12]. For small- and medium-sized Greek islands, the authors propose the installation and collaboration of a wind park, a small hydroelectric power plant, a water pump station, two water reservoirs, a properly sized desalination plant, and the usually existent thermal power plant as a back-up system.

Compared to Kaldellis' approach, in this calculation, the desalination unit acts as the deferrable or secondary load, answering the question of whether including water production into the energy supply system can benefit the overall system, even if the usage of water pump stations is not applicable. Various desalination processes are considered for meeting the requirements.

Desalination processes usually require a continuous energy supply and constant water flow. Some processes, though, are able to operate discontinuously and in part-load without damaging the distillation equipment or membranes in reverse osmosis systems, respectively [13-15]. Based on their flexibility, implementing such processes as dynamic load is very attractive, complementing consumer-induced load curves in stochastically fluctuating renewable energy supply systems.

In the last years, desalination processes underwent significant developments. Some processes, reverse osmosis (RO) and mechanical vapor compression (MVC), can adapt to a variable power source in a discrete manner, $c f$. Subiela et al. [16].

The presented approach firstly analyses an energy and water supply system using renewable energies, where desalination is integrated into the system in several designs.

A techno-economic optimization of combining electricity and water production is calculated for a Caribbean island in order to answer the following research questions:

- What is the techno-economic optimal energy supply system?

- What solutions do exist for integrating the energy demand of a desalination plant to the micro grid?

- Is there a benefit to integrate desalination as a deferrable load?

Four scenarios are identified to answer the listed research questions, shown in Table 1.

\section{Research object}

The small Caribbean island Petite Martinique, has a surface area of $2.4 \mathrm{~km}^{2}$ with a diameter of approximately 2 $\mathrm{km}$ and about 1,000 inhabitants. The island is mostly rural with a low level of infrastructure. The climatological conditions are subtropical with a mean temperature of around $25^{\circ} \mathrm{C}$, with a dry season from January to May and a wet season from June to December [17].

Value is mainly created by fishery, agriculture, and boat building. There is only a small tourism sector. Most farmers grow for their own consumption and domestic sale. The weather conditions and the fertile soil support agriculture, but water scarcity for irrigation limits further growth of this sector [18].

\section{Current electricity supply and renewable potentials}

According to measured data from Grenlec, the energy supplier of Grenada [19], the peak load on the island is $152 \mathrm{~kW}$ with an overall demand of $2.2 \mathrm{MWh} /$ day. The load curve, referred to as primary load, is available from logsheets in 1 -h steps for 1 year (2010). Figure 1 shows the seasonal load profile of Petite Martinique. Since there is no significant tourism and the climatic conditions in Petite Martinique are relatively constant, the variation of electricity consumption is quite flat.

The electric power is currently generated by two diesel generator sets. One of them was installed in 1976 with a capacity of $240 \mathrm{~kW}$ (Lister, Dursley, Gloucestershire, UK), the other one in 1999 with a nominal power of $210 \mathrm{~kW}$ (Caterpillar, Peoria, IL, USA). Mainly only one generator operates at a time.

The average price of $1-\mathrm{L}$ diesel was 1.13 USD in the year 2010. Due to long-term tendencies and the development of crude oil prices in the last years [20], an increase in diesel prices can be expected in the next decades, which motivates Grenlec to consider further investments into renewable energy technologies.

Wind velocities are taken from measurements on the neighboring island Carriacou, which is $5 \mathrm{~km}$ away from Petite Martinique. The highest wind speed occurs in January with $9.5 \mathrm{~m} / \mathrm{s}$ and the lowest in September with 5.6 $\mathrm{m} / \mathrm{s}$, while the annual average is $7.69 \mathrm{~m} / \mathrm{s}, c f$. Figure 2 .

Table 1 Energy and water supply scenarios

\begin{tabular}{|c|c|c|}
\hline & Energy & Water \\
\hline Scenario 1 & Serving primary load & No desalination \\
\hline Scenario 2 & Serving primary load & $\begin{array}{l}\text { Desalination using excess } \\
\text { energy only (not all water } \\
\text { demand met) }\end{array}$ \\
\hline Scenario 3 & $\begin{array}{l}\text { Serving primary load and } \\
\text { flexible, deferrable load }\end{array}$ & $\begin{array}{l}\text { Desalination when energy } \\
\text { is available }\end{array}$ \\
\hline Scenario 4 & $\begin{array}{l}\text { Serving primary load and } \\
\text { constant, secondary load }\end{array}$ & $\begin{array}{l}\text { Desalination with constant } \\
\text { water flow }\end{array}$ \\
\hline
\end{tabular}




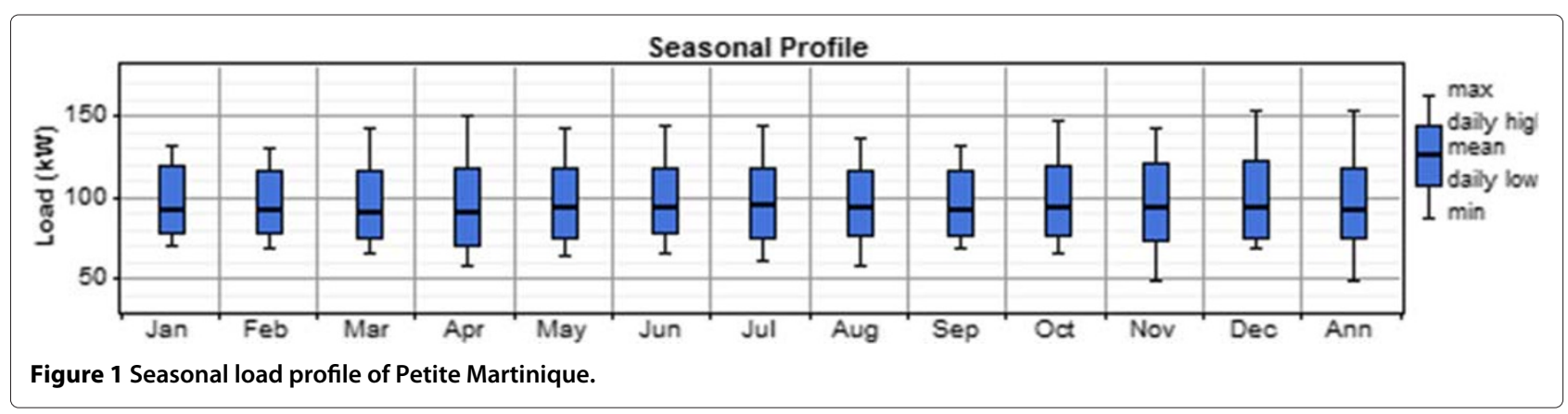

Looking at photovoltaic or solar thermal energy generation, solar radiation data are relevant. The scaled annual average of solar radiation in Petite Martinique is 6.57 $\mathrm{kWh} /\left(\mathrm{m}^{2 *}\right.$ day $)$, the lowest radiation is $5.9 \mathrm{kWh} /\left(\mathrm{m}^{2 *}\right.$ day $)$ in June and the highest $7.3 \mathrm{kWh} /\left(\mathrm{m}^{2 *}\right.$ day $)$ in March, $c f$. Figure 3.

\section{Current water supply}

The current water supply system is based on rain water harvesting and water imports from Grenada by tankers. The sustainable surface water sources are scarce in Petite Martinique. No public distribution system is installed. An existing reverse osmosis desalination plant with a capacity of $135 \mathrm{~m}^{3}$ /day was destroyed by a storm surge a couple of years ago.

In the dry season, January to May, residents have to prioritize their needs and the use of water accordingly. In order to provide sufficient freshwater for the households and agricultural purposes without the dependency on water imports, $150 \mathrm{~m}^{3} /$ day would need to be produced in the dry season and about $50 \mathrm{~m}^{3}$ /day in the wet season. This demand could be met by seawater desalination.

\section{Methods}

\section{Simulation and optimization}

Renewable energy concepts are mainly planned, developed, and dispatched by supporting tools like INSEL (doppelintegral GmbH, Stuttgart, Germany), TRNSYS (Thermal Energy System Specialists, LLC, Madison, WI, USA), Ebsilon (STEAG Energy Services GmbH, Essen, Germany), RETscreen (Natural Resources Canada, Quebec, Canada), HYBRID2 (Center for Energy Efficiency \& Renewable Energy, University of Massachusettes, MA, USA), HOMER (HOMER Energy, Boulder, CO, USA), and other programs.

The simulation for Petite Martinique is done with HOMER Energy, a simulation tool developed by the U.S. National Renewable Energy Laboratory. Compared to other simulation tools, HOMER has a very user-friendly interface and has undergone continuous developments, especially since becoming a commercial product (since 2009). Worldwide, various urban developers, utilities, and consultancies use HOMER for decentralized and gridconnected modeling and simulation [21].

In HOMER, the best possible system configuration is the one that satisfies the user-specified constraints at the lowest total net present cost. Finding the optimal system configuration may involve deciding on the mix of components that the system should contain, the size or quantity of each component, and the dispatch strategy the system should use [22].

The levelized costs of energy (LCoE) are calculated as shown in Equation 1, the levelized costs of water (LCoW) according to Equation 2. Both equations use the annuity

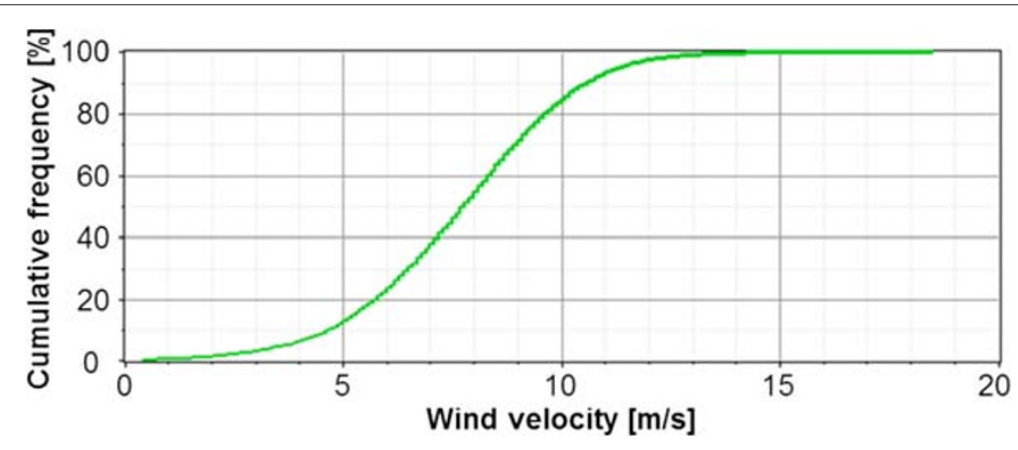

Figure 2 Wind velocities in Grenada. 


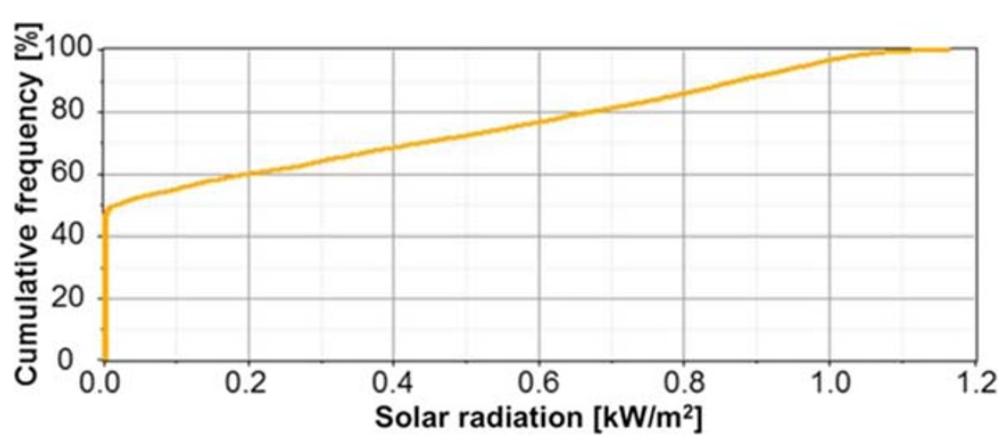

Figure 3 Solar radiation in Grenada.

factor $\left(A_{i, N}\right)$, where $i$ is equal to 0.075 and $N$ to 20 years (cf. Equation 3).

$$
\begin{aligned}
& \mathrm{LCoE}=\frac{I_{0_{\mathrm{E}}} * A_{i, N}+C_{\text {fuel }}+C_{\mathrm{O} \& \mathrm{M}_{\mathrm{E}}}}{E_{\text {prim }}} \\
& \mathrm{LCoW}=\frac{I_{0 \mathrm{~W}} * A_{i, N}+C_{\mathrm{O} \& \mathrm{MW}_{\mathrm{W}}}+C_{\mathrm{E}}}{W_{\text {year }}} \\
& A_{i, N}=\frac{i *(1+i)^{N}}{(1+i)^{N}-1}
\end{aligned}
$$

In Equation 1 the initial capital costs $\left(I_{0_{\mathrm{E}}}\right)$ multiplied by the annuity factor reflect the annual capital expenditures. $C_{\mathrm{O}_{\mathrm{M}}}$ stands for operation and maintenance costs of all components per year, and $C_{\text {fuel }}$ stands for annual fuel costs. All annual costs are divided by the primary load $\left(E_{\text {prim }}\right)$. The additional energy demand for desalination is not added to the primary load so as to keep the scenarios comparable without minimizing the LCoE due to the increased electricity demand. To calculate the LCoW, the initial capital cost of the desalination plant $I_{0_{\mathrm{W}}}$ multiplied by the annuity factor is added to the annual costs of the desalination plant, including operation and maintenance costs $\left(C_{\mathrm{O} \& \mathrm{M}_{W}}\right)$ and electricity costs $\left(C_{\mathrm{E}}\right)$. These are divided by the amount of potable water produced in the year $\left(W_{\text {year }}\right)$.

Within the simulation, hourly data sets over 1 year are considered. Based on Hoevenaars and Crawford [23], no greater temporal resolution is required here. The authors examined the efficacy of the temporal resolution in the range of $1 \mathrm{~s}$ to $1 \mathrm{~h}$ for a model that includes variable residential loads, wind, solar, diesel generator, and batteries. They found that system configurations using only a diesel generator as backup consume more fuel than determined by a model with hourly resolution. Configurations with only a battery backup were hardly affected by the time step. For systems with both diesel and battery backup, the optimal system costs were fairly close in all temporal resolutions but differed in the optimal component sizes. Since in the given case a diesel generator and batteries are used within all solutions, a resolution of 1-h time steps is sufficient without adulterating the results. For exact information about the share of fossil and renewable energies used in each time step, a higher temporal resolution would be required.

However, before implementing a supply system, an accurate dispatching strategy and frequency stabilization within each hour should be developed. Short-term energy storages as well as energy control and management systems need to be considered.

\section{Input data}

Within the simulation of HOMER, the currency used is USD. The project lifetime is determined to be 20 years considering a weighted average cost of capital of $7.5 \%$ for all scenarios. The diesel price of a 1-L diesel is 1.13 USD in Petite Martinique. The energy conversion technologies under consideration are diesel generators, wind converters, photovoltaic systems, and batteries. Due to the low energy demand, no further (largescale) renewable energy generation technologies such as wave energy conversion, concentrated solar power, and geothermal or waste incineration power plants are considered here.

\section{Diesel generator}

Within the simulation, two already existing sets of diesel generators - one Lister E6 and one Caterpillar 3408 are implemented in the model without adding any initial investment costs. In case of damages, replacement costs are calculated as $845 \mathrm{USD} / \mathrm{kW}$. With a determined lifetime of minimum 20 years $(180,000 \mathrm{~h})$ and one revision in that period, the costs of operation and maintenance (O\&M) are 5 USD/operating hour. Under the given circumstances in Petite Martinique (humidity, pressure, and density of air), the efficiency of the existent gensets varies in the range of $22 \%$ to $30 \%$ [19]. 


\section{Wind}

Only small-scale wind energy converters can be set up on the island (between 100 and $300 \mathrm{~kW}$ ). One reason for this is the relatively low peak demand and load profile; another reason has to do with difficulties in shipping due to the small harbor as well as to installation restrictions for heavy and large-sized equipment. Hurricane-proofed wind turbines are preferable in this region. Based on a comparative analysis, the Norwin wind turbine NW29 (225 kW; Norwin Wind Turbine Technologies, Gadstrup, Denmark) has been chosen. It uses a stall regulation system, has three blades, works at a hub-height of $30 \mathrm{~m}$, and runs with a cut-in speed of $4 \mathrm{~m} / \mathrm{s}$ and a cut-off speed of $25 \mathrm{~m} / \mathrm{s}$. The survival wind speed of the Norwin wind turbine is $67 \mathrm{~m} / \mathrm{s}$ and is hurricane-proven until level 5 on the Saffir-Simpson hurricane wind scale [24]. Based on an offer by the manufacturer, the costs for the NW29 in a Caribbean island are about 2,660 USD per installed kilowatt, and the O\&M costs including insurance are $5 \%$ of the investment costs [25].

\section{Photovoltaics}

The monthly arithmetic mean of the solar radiation in Petite Martinique is derived from NASA Atmospheric Science Data Center (Langley Research Center, Virginia, USA) [26], $c f$. Figure 3.

Data for 1 year in 1-h steps are generated by HOMER. Due to market research, MiaSole thin-film modules (Santa Clara, CA, USA), distributed by the only provider for Grenada and Petite Martinique, have been selected at turn-key costs of 4,000 USD/kW $\mathrm{kWak}_{\text {pea }}$ (including converter, installation, wire, etc.), and the O\&M costs are defined as $2 \%$ of the investment costs. It is a copper indium gallium selenide (CIGS) module with an assumed lifetime of 20 years and a derating factor of $80 \%$, including, e.g., aging, wiring, connection losses, dust, and shading [27]. The nominal operating cell temperature is $49^{\circ} \mathrm{C}$. An efficiency reduction due to high temperatures is considered with $-0.45 \% /{ }^{\circ} \mathrm{C}$. A module orientation towards the south is assumed with the azimuth being zero.

\section{Energy storage}

Depending on the capacity, the discharge power and discharge time range, various energy storage technologies can be applied for storing electricity. Since a capacity of less than $1 \mathrm{MWh}$ is sufficient for the energy system in Petite Martinique, typical large-scale bulk electricity storage technologies as high-temperature batteries such as sodium sulfur, pumped hydro, hydrogen storages, or compressed air energy storage systems are not applicable. Short-term electricity storages for frequency stabilization like flywheels, capacitors, and superconducting magnetic energy storages are also not considered.

As long-duration storages with frequent discharge, a lead-acid (LA) battery, a lithium ion (Li-ion) battery, and two flow batteries, zinc bromite $(\mathrm{ZiBr})$ and vanadium redox (V-redox), were compared. Table 2 gives a short overview of some parameters of these storage technologies. Within the table, $C_{\mathrm{E}}$ stands for the energy-related costs, $C_{\mathrm{O} \& \mathrm{M}}$ for the specific operation and maintenance costs, $\eta$ for the round-trip efficiency, and the maximum DOD for the depth of discharge.

Redox-flow batteries could become competitive in the near future, and other mentioned storage technologies could be beneficial in other cases, but based on the price and availability in the Caribbean islands, established lead-acid batteries are considered here. A lead-acid battery with a capacity of $2 \mathrm{~V} \times 3,000 \mathrm{Ah}=6 \mathrm{kWh}$ and a maximum depth of discharge of $70 \%$ was chosen for the simulations. Retailer prices are about 1,700 USD per battery.

\section{Desalination unit}

There are two main approaches used to desalinate sea or brackish water: thermal distillation or filtration. Two thermal and two electrical driven processes were analyzed: a thermal humidification-dehumidification process, a thermal multi-effect distillation process, an electrically driven MVC process, and an electrically driven RO process. Initial input data are based on market prices and the measured energy demands of manufacturers, which are comparable with market research results of ProDes [33].

Since, apart from the diesel generators' waste heat, no additional heat source (e.g., from producing industry) is available in the island; thermal desalination processes would require the installation of about $4,000 \mathrm{~m}^{2}$ thermal solar collector area. Considering a collector price of 400 $\mathrm{USD} / \mathrm{m}^{2}$ in Petite Martinique, a comprehensive analysis showed that these additional investment costs make thermal desalination processes economically unattractive for Petite Martinique, $c f$. Figure 4 [34].

Table 2 Electricity storage systems in comparison [28-32]

\begin{tabular}{lccccc}
\hline Parameter & Units & LA & Li-ion & ZnBr & V-Redox \\
\hline$C_{E}$ & USD/kWh & 250 to 350 & 600 to 700 & 300 to 400 & 15 to 20 \\
CO\&M & USD/kW/year & 5 to 10 & 20 to 25 & 0.6 to 0.7 & 15 to 20 \\
$\eta$ & & 0.75 to 0.8 & 0.8 to 0.9 & 0.9 to 1 & 0.6 to 0.7 \\
DOD & & 0.7 to 0.8 & 0.7 to 0.8 & 0.9 to 1 \\
\hline
\end{tabular}




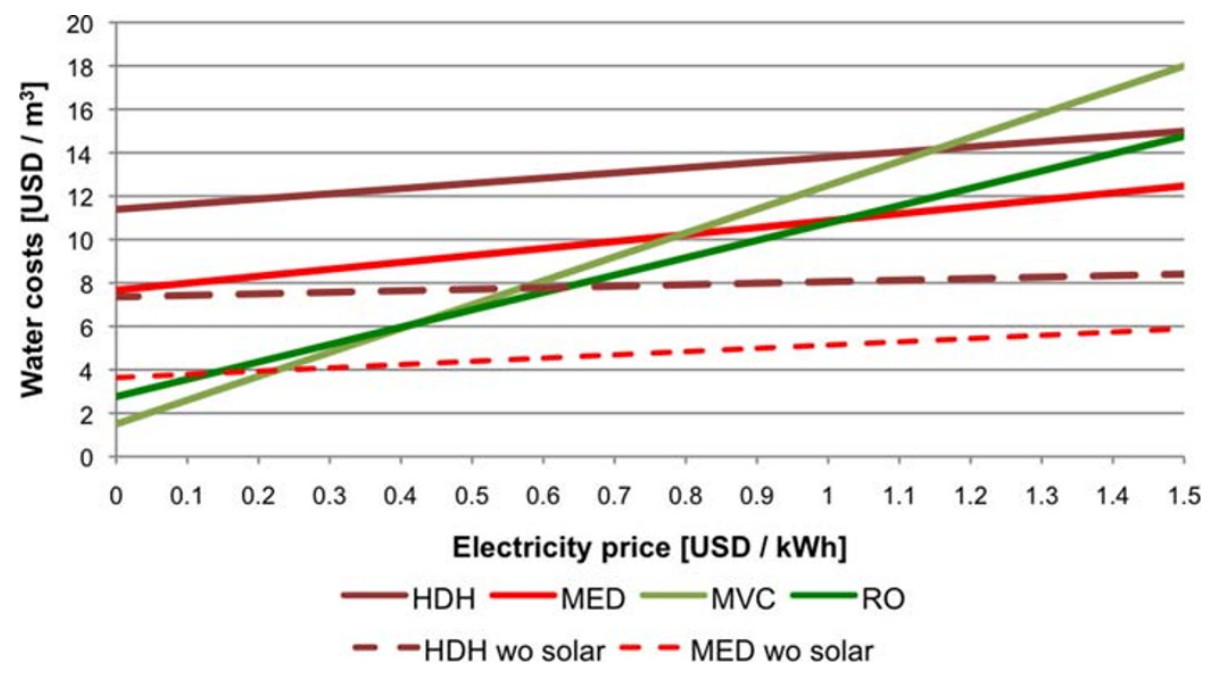

Figure 4 Comparison of different desalination processes.

The dashed lines in Figure 4 symbolize the costs of the thermal processes if free thermal heat would be available and no solar thermal collectors would need to be installed. But since no significant free waste heat is available in Petite Martinique, the dashed lines cannot be considered here and can only denote the potential of thermal processes. Clearly, for an electricity price under $0.43 \mathrm{USD} / \mathrm{kWh}, \mathrm{MVC}$ is the most favorable desalination process in the given case, whereas at higher electricity prices, RO would be the beneficial process. Electricity costs generated by the two thermal power plants are $0.52 \mathrm{USD} / \mathrm{kWh}$; electricity costs generated by the recommended hybrid system including renewables are about $0.31 \mathrm{USD} / \mathrm{kWh}$. Both electrical driven processes could be considered here. Since electricity prices are assumed to be under 0.43 USD, due to the implementation of renewable energy technologies, the MVC process is chosen for further simulations, $c f$. Figure 4.

Data of the mechanical vapor compression process considered here are based on personal interviews with representatives of the company Medesa [35]. The process requires $11 \mathrm{kWh} \mathrm{h}_{\mathrm{el}} / \mathrm{m}^{3}$ and has a load flexibility from $50 \%$ to $110 \%$. Medesa assumes that the process can be interrupted one to two times a day, decreasing the plant's lifetime approximately from 30 to about 25 years. Initial investment costs of such a plant are $3,000 \mathrm{USD} / \mathrm{m}^{3}$ installed, which would be about 450,000 USD for a desalination unit with a production capacity of $150 \mathrm{~m}^{3} /$ day (nominal capacity $180 \mathrm{~m}^{3} /$ day). O\&M costs are about 0.29 $\mathrm{USD} / \mathrm{m}^{3}[35]$.

\section{Water storage}

The benefit of producing freshwater at the time when surplus electricity is generated is the possibility to store water less expensively than electricity. As in most arid regions, no open water storage options are available in Petite Martinique; therefore, produced freshwater needs to be stored in tanks. Due to water quality reasons, a water storage capacity of $300 \mathrm{~m}^{3}$ is considered, which is able to cover the water demand for 2 days. Investment costs for storage tanks are not considered within the economical calculation since their cost is negligible compared to the main supply system.

\section{Results and discussion}

\section{Scenario 1: energy supply only}

In the first step, the optimal energy supply system is determined for Petite Martinique using the simulation interface of HOMER. Table 3 shows the optimal system setup of power generation for various scenarios. The first row stands for the current energy supply by diesel generators only; the second row shows the optimal system setup considering renewable energy sources and diesel generators. It consists of two Norwin wind turbines NW29, the two existent diesel gensets with a peak engine power of 210 and $240 \mathrm{~kW}$, and lead-acid batteries with a total capacity of $432 \mathrm{kWh}$. Photovoltaic power generation is not part of the optimal solution. The reason for this is the temperature effects as a breakdown showed.

Compared to the current system, by implementing wind energy converters, batteries, and other required applications, the overall costs of electricity can significantly be minimized from $0.52 \mathrm{USD} / \mathrm{kWh}$ to 0.31 $\mathrm{USD} / \mathrm{kWh}$ for a period of 20 years, $c f$. Table 3. A system change towards renewables, though, include relatively high investment costs. The corresponding energy balances are shown in Table 4. The capacity utilization factor of the wind converters is 3,270 full load hours per year. 
Table 3 Optimal energy supply systems of scenarios 1 to 4

\begin{tabular}{lccccccc}
\hline & $\begin{array}{c}\text { Wind } \\
(\mathbf{k W})\end{array}$ & $\begin{array}{c}\text { Battery } \\
\mathbf{( k W h}\end{array}$ & $\begin{array}{c}\text { Diesel } \\
\mathbf{( L )}\end{array}$ & $\begin{array}{c}\text { Invest. (El) } \\
(\mathbf{U S D})\end{array}$ & $\begin{array}{c}\text { Invest. (Des) } \\
(\mathbf{U S D})\end{array}$ & $\begin{array}{c}\text { LCoE }_{\text {prim-load }} \\
(\mathbf{U S D} / \mathbf{k W h})\end{array}$ & $\begin{array}{c}\text { LCoW } \\
\left(\mathbf{U S D} / \mathbf{m}^{\mathbf{3}}\right)\end{array}$ \\
\hline Current system & - & - & 335,700 & - & - & 0.52 & - \\
Scenario 1 & 450 & 432 & 68,200 & $1,422,400$ & - & 0.31 & - \\
Scenario 2 & 450 & 432 & 68,200 & $1,422,400$ & 550,000 & 0.31 & 0.36 \\
Scenario 3 & 450 & 432 & 97,700 & $1,422,400$ & 550,000 & 0.32 & 1.91 \\
Scenario 4 & 450 & 576 & 127,400 & $1,508,200$ & 550,000 & 0.43 & 1.91 \\
\hline
\end{tabular}

Invest., initial investment costs. El., Electricity supply system. Des., Dealination unit.

Transmission losses are not accounted in the balances in Table 4.

Gaining increasing independence from oil imports and, therefore, stable energy prices in the long-term represents beneficial opportunities of scenario 1 . There is also a clear ecological benefit: 267,500 L of diesel could be saved in scenario 1 compared to the current supply system. A considerable amount of emissions could be avoided, e.g., about 705 tons of $\mathrm{CO}_{2}$, just to name one of the greenhouse gases.

In scenario 1, water production has not yet been considered. That means that implementing renewable energy sources into the current energy system is already beneficial even without considering the water production as in the case of scenarios 2,3 , and 4 .

\section{Scenario 2: water production by excess electricity of renewable fraction only}

Analyzing the deviation of every hour within the 1-year simulation of scenario 1, a remarkable excess of generated electricity by the wind converters can be determined. In Figure 5, the daily average load and daily average wind power generation are shown. Hourly fluctuations are not noticeable in this daily resolution.

After meeting the electricity demand of all consumers and filling the batteries, the surplus electricity could be used for alternative purposes. On a dry island like Petite Martinique, producing water and supplementing the existing water stocks is an optimal solution, if additionally required investments do not exceed a reasonable amount.

Costs for desalination can be kept low if energy costs for the desalination process are low. In electrically driven processes, like the one considered here, about $44 \%$ of the overall desalination costs are energy costs [36]. Therefore, the usage of free excess electricity reduces costs significantly.

To determine the potential of producing potable water by excess electricity in Petite Martinique, the hourly data sets are converted to daily and weekly values according to Equation 4. This way, shortages and surpluses meeting the daily demand of freshwater are more visible. Water storage tanks can guarantee a reliable and constant availability of freshwater within the presented weeks.

$$
\begin{aligned}
W_{\text {week }} & =\sum_{i=1}^{144} W_{i} \\
W_{i} & =\frac{E_{i}}{E_{\text {desal }}}
\end{aligned}
$$

The produced amount of water per hour $\left(W_{i}\right)$ results from the available excess electricity $\left(E_{i}\right)$ each hour divided by the energy consumption of the desalination plant $\left(E_{\text {desal }}\right)$, which is assumed to be $11 \mathrm{kWh} / \mathrm{m}^{3}$. Taking into account that the desalination plant has an hourly nominal

Table 4 Energy and water balances per year

\begin{tabular}{lcccccc}
\hline & $\begin{array}{c}\text { Gen. el. diesel } \\
(\mathbf{M W h})\end{array}$ & $\begin{array}{c}\text { Gen. el. wind } \\
(\mathbf{M W h})\end{array}$ & $\begin{array}{c}\text { Served load } \\
(\mathbf{M W h})\end{array}$ & $\begin{array}{c}\text { Served load for } \\
\text { water (MWh) }\end{array}$ & $\begin{array}{c}\text { Excess el. } \\
(\mathbf{M W h})\end{array}$ & $\begin{array}{c}\text { Produced water } \\
\left(\mathbf{1}, \mathbf{0 0 0} \mathbf{~ m}^{\mathbf{3}}\right)\end{array}$ \\
\hline Current system & 819 & - & 819 & - & - & - \\
Scenario 1 & 158 & 1,288 & 819 & - & 627 & - \\
Scenario 2 & 158 & 1,288 & 819 & 293 & 334 & 323 \\
Scenario 3 & 221 & 1,288 & 819 & 367 & 382 & 33 \\
Scenario 4 & 280 & 1,288 & 819 & 367 & 33 & 33 \\
\hline
\end{tabular}

Gen. el., generated electricity. Excess el., excess electricity. 


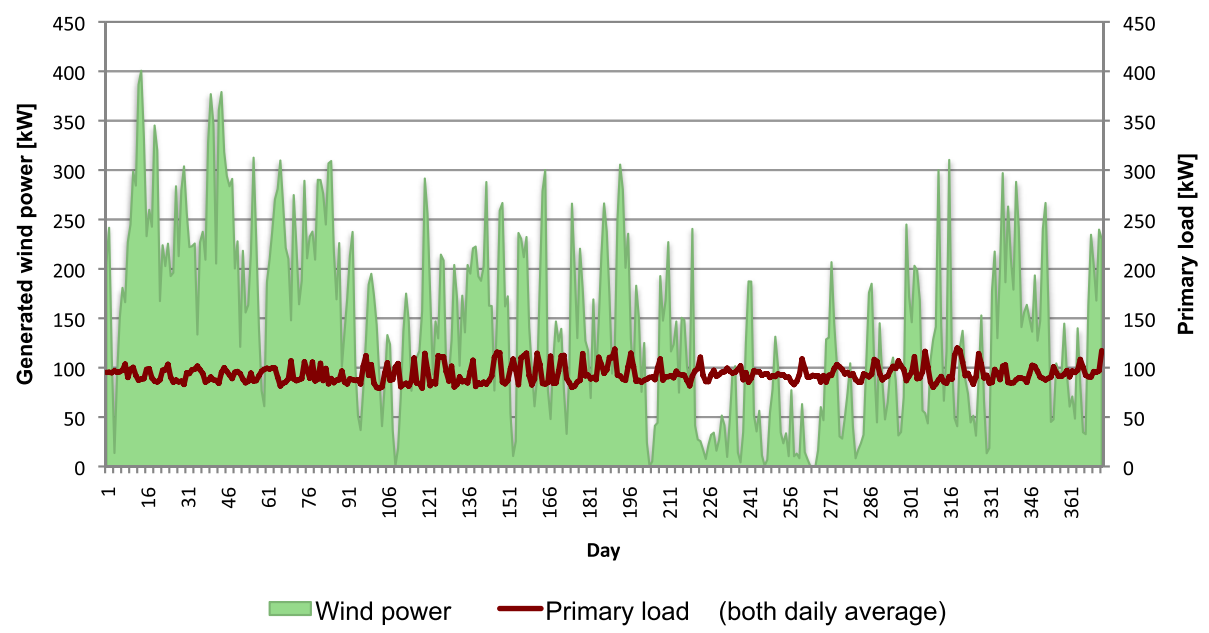

Figure 5 Load and power generation by wind converters.

capacity of $8.25 \mathrm{~m}^{3}$, the restrictions in Equation 5 have to be considered.

$$
W_{i}=\left\{\begin{array}{c}
0 \mathrm{~m}^{3} \text { if } E_{i}=0 \mathrm{kWh} \\
\frac{E_{i}}{E_{\text {desal }}} \text { if } 0 \mathrm{kWh}<E_{i} \leq 90.75 \mathrm{kWh} \\
8.25 \mathrm{~m}^{3} \text { if } E_{i}>90.75 \mathrm{kWh}
\end{array}\right.
$$

Due to these restrictions, not all excess wind energy can be converted and used for freshwater production. Using the energy generation data of scenario 1, Figure 6 shows the potential of water production on the island. The red line displays the overall water demand for the whole year during each week. The dark columns in the background highlight the theoretical potential of water production using excess electricity; the light columns show the real potential based on the technical production restrictions of the desalination plant (cf. Equation 5). Hourly data are not identifiable in this diagram. Since the water storage is dimensioned for 2 days only, filled bars of some weeks cannot be shifted to other weeks, e.g., from week 20 to 21 .

Figure 6 exemplifies that excess electricity generated by renewables could produce up to twice as much water as needed occasionally. Particularly favorable is that a major part of water demand in the dry season from January to May can be met immediately because wind conditions are very good. It also proves, however, that wind energy

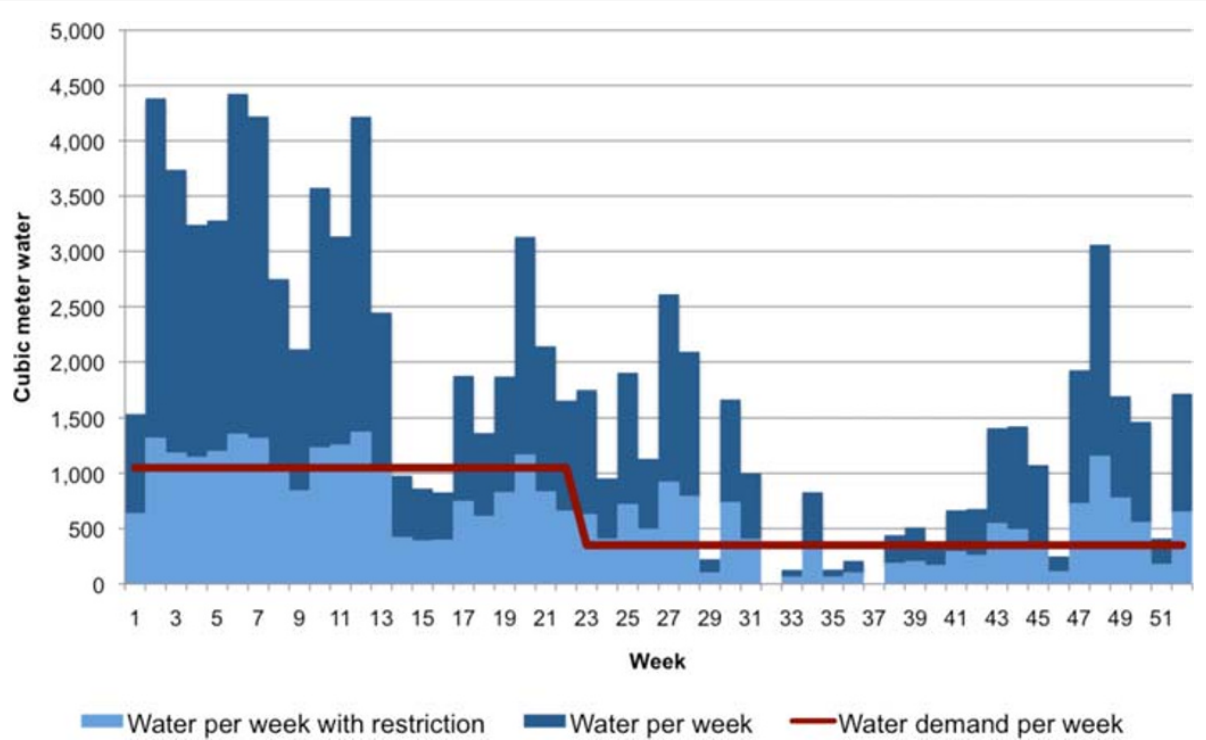

Figure 6 Water demand and production potential by excess electricity of renewable energy fraction. 
cannot guarantee a continuous and reliable water supply throughout the whole year. That means that diesel generators either need to run during periods of no wind and high water demand, which could eventually undo the former economic and ecological advantage, or the overall energy supply system needs to be adjusted to the additional electricity demand.

\section{Scenario 3: water production as a deferrable load}

In the scenarios 1 and 2 , only the primary load was served, and excess electricity was used for water production. In scenario 3, a further load is added that needs to be served. It can be deferred as long as it meets the constraints within a given period, in this case within daytime. If not enough excess energy is available, diesel generators need to operate in order to serve the so-called deferrable load. Here, the deferrable load is the energy consumption of a flexible operating desalination plant with a specific daily water production. A water storage is acting as a temporary buffer storage.

In HOMER, a deferrable load can be approximated as an electric load. In order to represent water desalination as an electric load, the following input data are determined for scenario 3: as deferrable load, an average daily energy consumption of $1,650 \mathrm{kWh} /$ day $\left(11 \mathrm{kWh} / \mathrm{m}^{3}\right.$ for $150 \mathrm{~m}^{3}$ water) is assumed for the dry season from January to May, and $550 \mathrm{kWh} /$ day for the remaining wet months. The water storage capacity of $300 \mathrm{~m}^{3}$ is represented by a 3,300-kWh electrical storage capacity. The peak load is $220 \mathrm{~kW}$ for an hourly water production of $7.5 \mathrm{~m}^{3} / \mathrm{h}$. Operating the desalination plant $10 \%$ above the nominal power, $8.25 \mathrm{~m}^{3} / \mathrm{h}$ can be produced at the mentioned peak load of $90,75 \mathrm{~kW}$.

Row four in Table 3 shows the simulation results of scenario 3 . In contrast to scenario 2 , where not all water demand is met, scenario 3 meets all energy and water demand, $c f$. Table 4. At first glance, the increased energy demand for water production did not change the energy supply system significantly. There are still two Norwin NW29 wind turbines installed and still the same capacity of batteries required. In periods of electricity shortage, the diesel generators operate more, using about 97,700 instead of $68,200 \mathrm{~L}$ of diesel per year. Accepting a higher diesel consumption, no additional investment costs are required for the energy supply system compared to scenario 2 . Only the initial investment costs for the desalination plant and, eventually, a new water storage tank would have need to be added to the overall system costs compared to scenario 1 .

When evaluating costs, the last two columns of Table 3 are meaningful. Using Equations 1, 2, and 3, the levelized costs of electricity and of water differ significantly between the scenarios. Compared to the current system, the energy costs are lower in scenarios 1 and 2 because of the strongly reduced diesel consumption. In scenario 3, the levelized costs of electricity are higher. The reason for this is that in order to meet all water demand, contrary to scenario 2, additional energy must be provided for periods without sufficient wind. Since this demand is met by fuel-consuming diesel generators, higher energy generation costs are the result. But not only the costs are higher, a much higher electricity demand is met as well, due to the included desalination plant (3.2 MWh/day instead of 2.2 $\mathrm{MWh}$ /day in scenario 1).

Comparing the levelized costs of water $\left(2.32 \mathrm{USD} / \mathrm{m}^{3}\right.$ in scenario 2 and $1.91 \mathrm{USD} / \mathrm{m}^{3}$ in scenario 3 ), water costs in scenario 3 are less than those in scenario 2 . The reason is that instead of $27,000 \mathrm{~m}^{3}$ freshwater, like in scenario 2, $33,000 \mathrm{~m}^{3}$ is produced in scenario $3, c f$. Table 4 ; therefore, the investment costs can be distributed to more cubic meters, and the levelised costs shrink.

\section{Scenario 4: water production as a secondary load}

For both scenarios 2 and 3, a desalination process was presumed that is able to operate discontinuously and with a flexible load depending on available energy. Conventional desalination units though are designed to perform at an optimal level and to operate continuously at a constant rate. As comparison, in scenario 4, the energy consumption of such a desalination plant is integrated into the system as a secondary load. In this case, the secondary load is a constant load all the year round, neglecting periods of maintenance. That means, this secondary load is not adjusting to the wind conditions, and the diesel generators need to operate whenever wind energy cannot meet the demand. The generator sets operate more hours and consume significantly more fuel in scenario 4 than in scenario 3 (127 tons instead of previously 98 tons of diesel) . The last row in Table 3 illustrates the results of scenario 4 . The initial investment costs increase due to additionally required energy storage capacities. The levelized costs of energy reflect the higher costs of the overall system.

The levelized costs of water are equivalent to scenario 3 because the desalination costs and the amount of water produced are the same. Due to the optimized operation, O\&M costs of the desalination plant could be slightly lower than in scenario 3 . This difference though is not considered here.

Energy costs for the desalination plant are set to zero. The levelized costs of energy of all scenarios are based on the primary load only, making the energy costs comparable without interfering changes on the water cost side.

\section{Levelized costs of electricity and water}

Looking into the presented scenarios, various results can be discussed. One interesting result is the shifting of levelized costs of electricity and water. 
Decision makers often face difficulties in justifying high investments and presenting refinancing strategies [34]. The question of whether electricity or water is more valuable for a region can be important for developing payback strategies. All presented scenarios optimize the supply system based on the energy demand. Figure 7 sensitizes the viewer for cost structures. The three scenarios combining power generation and water production are visualized by three graphs. They illustrate the dependency of LCoE and LCoW. Overall system costs can be financed by sold water and/or sold electricity. At each point on the graphs, the entire system costs are covered. The marked points on the graphs show the LCoE and LCoW calculated for scenarios 2, 3, and 4, $c f$. Table 3.

The levelized costs of energy and water are based on the Equations 1, 2, and 3. The considered primary load of the island $E_{\text {prim }}$ in Equation 1 is $819 \mathrm{MWh} /$ year; the produced amount of potable water $W_{\text {produced }}$ in Equation 2 equals to $26,600 \mathrm{~m}^{3}$ /year for scenario 2 and to $33,600 \mathrm{~m}^{3}$ /year for scenarios 3 and 4 . The overall energy and water balances of all scenarios in a year are shown in Table 4. At the interception point with the $x$-axis, water costs are zero, meaning that the water can be given out for free. This is enabled by financing the water production, including initial, O\&M, and energy costs through higher electricity prices for the end user. The interception points with the $y$-axis show LCoW providing free serving of the primary load. All the power generation costs are paid by the water consumers in this case.

Comparing scenario 2 (red dashed line with points) and scenario 3 (light blue dashed line) the graphs cross at a
LCoW of $6.00 \mathrm{USD} / \mathrm{m}^{3}$ and LCoE of $0.19 \mathrm{USD} / \mathrm{kWh}$. At this point, both scenarios perform economically equally. Reiterating the difference between scenarios 2 and 3, in scenario 2, about $6,000 \mathrm{~m}^{3}$ /year less freshwater can be produced than in scenarios 3 and 4 .

If a system is supposed to be refinanced exclusively by sold electricity and the water demand does not need to be met completely, scenario 2 is the best solution. If all water demand should be met, scenario 3 is the most attractive system setup. The graph of scenario 4 (dark blue line) is parallel to the one of scenario 3 because the same amount of electricity and water is served. Due to the inflexible energy demand of the desalination plant, scenario 4 performs as the least profitable solution in all cases. As its desalination unit is not able to react to fluctuating wind power, more diesel fuel is consumed, increasing the overall system costs.

\section{Conclusions}

Summarizing the main results of a combined energy and water supply system for Petite Martinique, scenario 1 points out that an extension of the current energy supply system using renewable energy technologies reduces power generation costs. It can be concluded that the techno-economic optimal energy supply system consists of two NW29 wind turbines, the two existent diesel generator sets, and lead-acid batteries with a total capacity of $432 \mathrm{kWh}$. The energy demand of a desalination plant can be integrated to the micro grid in three different ways: using only excess electricity, producing less water than needed (scenario 2), as deferrable load (scenario 3) or as constant secondary load (scenario 4).

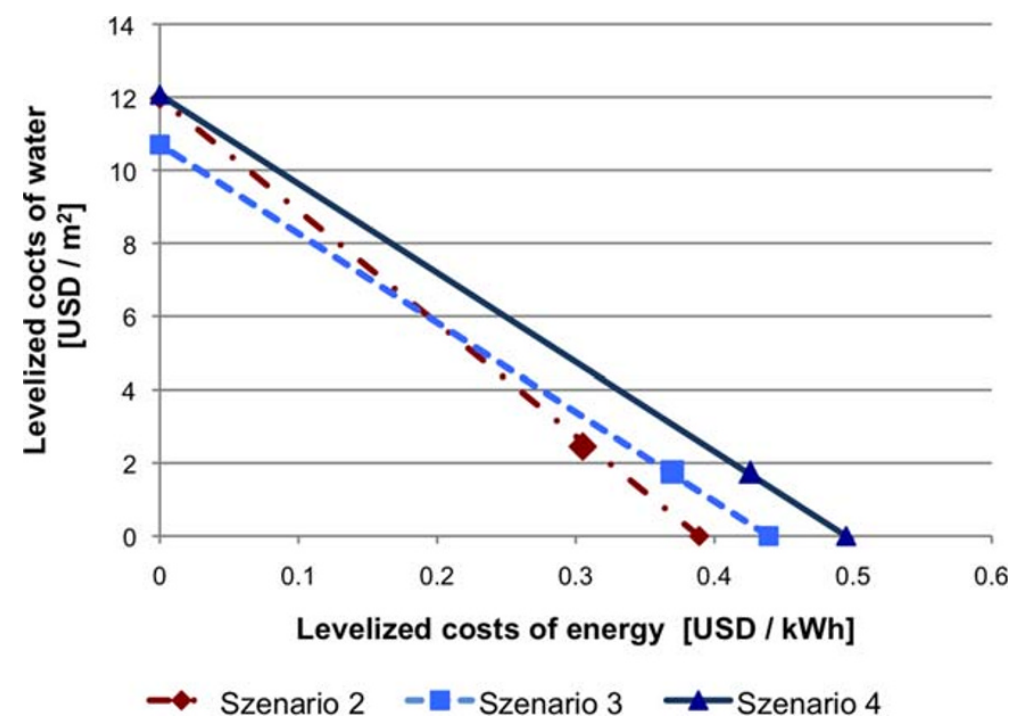

Figure 7 Levelized costs of energy and water. 
Scenario 2 shows that the calculated energy supply system of scenario 1 is able to cover a significant part of a desalination plant's energy demand just by renewable and free excess electricity. Saving energy costs for a desalination plant, which is responsible for almost half of the water costs, makes desalination attractive as alternative to freshwater imports. In scenario 3 , the desalination plant's energy consumption acts as a deferrable load. An extension of the energy supply system by further components is not required. In periods when no excess wind energy is available, the existent diesel generators function as a backup. In scenario 4, a conventional desalination plant is considered, which requires a continuous water flow and, therefore, a constant energy supply. Additional energy storage capacities are required, and more fuel is consumed. Therefore, scenario 4 cannot compete with scenarios 2 and 3, which highlight the value of an integrated supply system. Comparing scenarios 3 and 4, the clear benefit is reflected by the levelized costs of electricity and water. Scenario 3 performs best. For an optimal energy and water supply system on the island, the desalination plant's energy demand should be integrated as deferrable load.

A further analysis of the levelized costs of electricity and water points out possible cost structures for developing payback strategies. Investments can be refinanced either by higher energy and/or higher water costs. Depending on the priorities, scenario 2 is the optimal solution if the production of less than $150 \mathrm{~m}^{3} /$ day is sufficient on the island. Scenario 3 is the best system setup if all water demand needs to be met.

No dispatching strategies and short-term energy storages are addressed within this paper. A further breakdown of hourly data sets is required to validate the capability of desalination processes to operate discontinuously and in part-load ranges.

\begin{abstract}
Abbreviations
$A_{i, N}$, annuity factor; $C_{E}$, specific energy cost; $C_{O \& M_{E}}$, operation and maintenance costs of energy supply system; $C_{0 \& M_{W}}$, operation and maintenance costs of desalination plant; $E_{\text {desal, }}$ energy consumption of desalination plant per cubic meter of potable water; $E_{i}$, Excess energy by renewable energies per hour; Eprim, primary load on the island; $i$, interest rate; $I_{O_{E}}$, initial capital costs of energy supply system; $I_{0,}$, initial capital costs of desalination plant; $L C o E$, levelized costs of electricity; LCoW, levelized costs of water; MVC, mechanical vapor compression (desalination process); N, project lifetime; $\mathrm{O} \& \mathrm{M}$, operation and maintenance; $\mathrm{RO}$, reverse osmosis (desalination process); USD, United States Dollar; $W_{i}$, produced amount of potable water per hour; $W_{\text {week, }}$ produced amount of potable water per week; $W_{\text {year, }}$ produced amount of potable water per year.
\end{abstract}

\section{Competing interests}

The authors declare that they have no competing interests.

\section{Authors' contributions}

$\mathrm{KB}$ and $\mathrm{PB}$ developed the methodology and applied it with gathered input data. In addition they analyzed and described the results. FB led and coordinated the study and affected its design. All authors read and approved the final manuscript.

\section{Acknowledgements}

We would like to thank Robert Blenker, WRB Enterprise, and Jusceno Jacobs, Grenlec, for the very valuable and friendly collaboration and for supplying us with all data needed for this research work. We also thank all experts of the energy generation and desalination industry for supporting this work even with internal data and personal interviews.

\section{Author details}

${ }^{1}$ Department of Energy Engineering, Technische Universität Berlin, Fasanenstrasse 89, Berlin, 10623, Germany. ${ }^{2}$ Reiner Lemoine Institut gGmbH, Ostendstrasse 25, Berlin, 12459, Germany.

Received: 21 September 2011 Accepted: 15 July 2012

Published: 16 July 2012

\section{References}

1. AOSIS (2001) Report of the Third Alliance of Small Island States. In: Third AOSIS Workshop on Climate Change, Energy and Preparations for Ninth Session of Commission on Sustainable Development. www.sidsnet.org/ docshare/energy/FinalRptCyprus.doc. Accessed 20 Dec 2010

2. Weisser $D(2004)$ On the economics of electricity consumption in small island developing states: a role for renewable energy technologies? Energy Policy 32: 127-140

3. Mitra I (2006) A renewable island life: electricity from renewables on small islands. Refocus 7(6): 38-41

4. Livengood D, Sim-Sim FC, loakimidis CS, Larson R (2010) Responsive demand in isolated energy systems. In: Island Sustainablity, Volume 130 of WIT Transactions on Ecology and the Environment. WIT Press, Southhampton, pp 197-207

5. Garcia-Rodriguez L, Romero-Ternero V, Gomez-Camacho C (2001) Economic analysis of wind-powered desalination. Desalination 137: 259-265

6. Kaldellis JK, Kondili EM (2007) The water shortage problem in the Aegean archipelago islands: cost-effective desalination prospects. Desalination 216: 123-138

7. Cipollina A, Micale G, Rizzuti, L (eds) (2009) Seawater desalination. Springer, Heidelberg, pp 131-272

8. Tzen E, Morris R (2003) Renewable energy sources for desalination. Solar Energy 75: 375-379

9. Kalogirou SA (2005) Seawater desalination using renewable energy sources. Prog Energy Combust Scie 31: 242-281

10. Garcia-Rodriguez L (2003) Renewable energy applications in desalination: state of the art. Solar Energy 75: 381-393

11. Mathioulakis E, Belessiotis V, Delyannis E (2007) Desalination by using alternative energy: review and state-of-the-art. Desalination 203: 346-365

12. Kaldellis JK, Kavadias KA, Kondili E (2006) Energy and clean water coproduction in remote islands to face the intermittent character of wind energy. Int J Global Energy Issues 25: 298-312

13. Witte T, Siegfriedsen S (2003) WindDeSalter Technology, Direct use of wind energy for seawater desalination by vapour compression or reverse osmosis. Desalination 156: 275-279

14. Paulsen K, Hensel F (2007) Design of an autarkic water and energy supply driven by renewable energy using commercially available components. Desalination 203: 455-462

15. Pohl R, Kaltschmitt M, Hollaender R (2009) Investigation of different operational strategies for the variable operation of a simple reverse osmosis unit. Desalination 249: 1280-1287

16. Subiela VJ, JG, Cara JA (2004) The SDAWES project: lessons learnt from an innovative project. Desalination 168: 39-47

17. World Travel Guide (2011) Grenada Weather and Climate. http://www worldtravelguide.net/grenada/weather. Accessed 16 Feb 2011

18. Javan Williams (2011) Water Data Petite Martinique. Ministry of Carriacou and Petite Martinique Affairs. http://www.gov.gd/ministries/ carriacou_pm_affairs. Accessed 14 Feb 2011

19. Grenada Electricity Services Ltd (2011) Specific data about the current energy supply system of Petite Martinique. http://www.grenlec.com. Accessed 24 Jan 2011

20. Oil-price net (2011) Crude oil price. http://www.oil-price.net. Accessed 21 Apr 2011

21. HOMER (2010) Energy modeling software for hybrid renewable energy systems. www.homerenergy.com. Accessed 20 Oct 2010 
22. Lambert T, Gilman P, Lilienthal P (2006) Micropower system modeling with, HOMER. In: Integration of alternative sources of energy. IEEE, Wiley-Interscience, Hoboken, pp 379-418

23. Hoevenaars EJ, Crawford CA (2012) Implications of temporal resolution for modeling renewables-based power systems. Renewable Energy 41 285-293

24. National Hurricane Center U (2011) The Saffir-Simpson hurricane wind scale. http://www.nhc.noaa.gov/aboutsshs. Accessed 09 Feb 2011

25. Norwin A/S (2011) NORWIN 29 - STALL - 225 kW - Data-sheet. Costs from specific offer. http://www.norwin.dk. Accessed 18 Feb 2011

26. NASA Atmospheric Science Data Center (2011) Surface meteorology and solar energy (SSE) data and information. http://eosweb.larc.nasa.gov/ PRODOCS/sse/table_sse.html. Accessed 24 Nov 2010

27. Burkhardt K (2011) GrenSol - Grenada Solar Power Ltd. Costs from specific offer. http://www.grensol.com

28. Schoenung SM, Hassenzahl WV (2003) Long- vs. short-term energy storage technologies analysis: a life-cycle cost study, Technical Report SAND2003-2783, Sandia National Laboratories. [A Study for the DOE Energy Storage Systems Program]

29. Schoenung SM (2011) Energy storage systems cost update, Technical Report SAND2011-2730, Sandia National Laboratories. [A Study for the DOE Energy Storage Systems Program]

30. Kaldellis JK, Zafirakis D, Kondili E (2010) Optimum sizing of photovoltaic-energy storage systems for autonomous small islands. Electrical Power and Energy Systems 32: 24-36

31. Kaldellis JK, Zafirakis D, Kavadias K (2009) Techno-economic comparison of energy storage systems for island autonomous electrical networks. Renewable and Sustainable Energy Rev 13: 378-392

32. Coppez G, Chowdhur S, Chowdhur SP (2010) Review of battery storage optimisation in distributed generation. In: Power Electronics, Drives and Energy Systems (PEDES) \& 2010 Power India. New Delhi, 20-23 Dec 2010, pp 1-6

33. Papapetrou M, Wieghaus M, Biercamp C (2010) Roadmap for the development of desalination powered by renewable energy. Tech. rep., Prodes. http://www.prodes-project.org/. Accessed 10 Nov 2010

34. Blechinger P (2011) Energy and water supply system for Petite Martinique regarding renewable energies. Technische Universität Berlin, Berlin

35. Medesa (2011) MVC desalination. Personal communication with D. Siegmund, head of sales, Medesa Technology $\mathrm{GmbH}$, d.siegmund@medesa-technology.de.www.medesa.de. Accessed 10 Jan 2011

36. Committee to Review the Desalination and Water Purification Technology Roadmap NationalResearchCouncil (2004) Review of the desalination and water purification technology roadmap. National Academies Press, Washington, D.C

doi:10.1186/2192-0567-2-14

Cite this article as: Bognar et al:: Seawater desalination in micro grids: an integrated planning approach. Energy, Sustainability and Society 2012 2:14.

\section{Submit your manuscript to a SpringerOpen ${ }^{\circ}$ journal and benefit from:}

- Convenient online submission

- Rigorous peer review

- Immediate publication on acceptance

- Open access: articles freely available online

- High visibility within the field

- Retaining the copyright to your article

Submit your next manuscript at $\boldsymbol{p}$ springeropen.com 